\title{
The impact of El Nino and La Nina weather patterns on Canterbury water resources
}

\author{
$\underline{\text { M. Mohssen }}^{a}$, S. Edwards ${ }^{\text {a }}$, A. S. Walters and N. A. Alqassab ${ }^{\text {a }}$ \\ ${ }^{a}$ Lincoln University, New Zealand \\ Email: magdy.mohssen@lincoln.ac.nz
}

\begin{abstract}
Water is an extremely important and increasingly contentious resource in the Canterbury region. An accurate assessment of the size and behaviour of the resource is fundamental to effective water management. This study attempts to calculate rainfall, runoff and evapotranspiration (ET) for Canterbury in order to ascertain a regional water balance as a means of quantifying a net excess or deficit of water in the hydrological budget. The effect of the El Nino Southern Oscillation (ENSO) on this water balance is investigated. Water balances are calculated for two 'mega-catchments'; western or 'Alpine' Canterbury, from the Southern Alps to the foothills, and eastern or 'Plains' Canterbury. Long term averages (LTA) are compared with the two strongest years of positive and negative ENSO in the last thirty years, as measured by the Southern Oscillation Index (SOI).
\end{abstract}

The water balance of the Alpine catchment proved problematic, with a significant deficit result. This is thought to be due to major underestimation of rainfall in the alpine region resulting from poor distribution of rainfall gauges. The rainfall figures were recalculated by addition of runoff and ET. The resulting rainfall figures show an increase in rain from LTA for El Nino years and an even greater increase for La Nina, although the high variability in rain means these differences are not statistically significant.

This research indicates that there is an impact of strong ENSO events on the water budget components of Canterbury, New Zealand. La Nina conditions tend to produce increased rainfall and decreased evapotranspiration compared to El Nino conditions. The Plains catchment is where the pressure on the water resources is greatest. The LTA's produce an annual excess of $94 \mathrm{~mm}$, while El Nino years with lower rainfall and higher ET, produced a deficit of $65 \mathrm{~mm}$. La Nina years have rainfall between the LTA and El Nino years, but a lower ET than either, and produces a deficit of $10 \mathrm{~mm}$. Due to data and modeling inaccuracies the La Nina deficit is not large enough to be considered certain.

Availability of accurate measured data across the catchments proved to be a major issue for this study. As a result a mixture of measured and modeled data is used and results should be treated with caution. It is recommended that significant investment be made in increasing the capacity of the region to accurately quantify its water resources.

Keywords: Hydrologic Budget, ENSO, SOI, El Nino, La Nina, ET 


\section{INTRODUCTION}

Quantification of the elements of a water balance of a region can allow insight into water availability, spatial and temporal distributions, and the effects of both natural and man induced changes to inputs and abstractions. In New Zealand, few studies have evaluated components of the water budget at a national level (Toebes 1972; Woods et al, 2006), at individual river catchment levels (Freestone, 1981; Schmidt et al 2009) and at regional level (Baalousha, 2008). However, despite the demand on this precious resource, no study appears to have calculated an overall water balance for the Canterbury region. Various studies have undertaken modeling of individual components, primarily surface and river recharge to groundwater aquifers of the Canterbury Plains (White et al, 2003; Morgan et al, 2002; Scott, 2003).

Precipitation is usually the most important input into a hydrological system and any factors which significantly affect rainfall can have a major impact on the water balance. Oceanic and atmospheric phenomenon in the equatorial Pacific Ocean, known as the El Nino Southern Oscillation (ENSO), has been linked to precipitation variability in the South Island of New Zealand (Mullan 1998; Kidson and Renwick, 2002; McKerchar et al, 1998). The Southern Oscillation Index (SOI) measures the pressure difference between Darwin, Australia and Tahiti in the mid Pacific and provides a measure of the ENSO. Negative SOI values indicate an El Nino event with oceanic warming in the eastern Pacific and high atmospheric pressure in the western Pacific. Studies have indicated that a strong El Nino event produces stronger summer westerly flows over New Zealand with higher precipitation in the west as a result, with often drier conditions in the east. In contrast, La Nina events are indicated by positive SOI values which, although less impactful on New Zealand weather, tend to produce more common and stronger north-east flows with higher precipitation in the north and east (Gordon, 1986; Mullan, 1996 and 1998; Kidson and Renwick, 2002,) The ENSO has been found to have significant influence on hydrological budgets of the New Zealand's southern lakes (McKerchar and Pearson, 1994. McKerchar et al, 1996 and 1998). The farm gate cost alone of the 1997/98 El Nino event is estimated at $\$ 425 \mathrm{M}$ (Basher, 1998). However, despite the evidence for an ENSO effect on New Zealand weather patterns, there are also many other influences and there is little certainty around 'typical' ENSO characteristics. East coast drought may occur in one El Nino event but not another, and also may occur in La Nina years (Basher, 1998). That said, some studies have indicated around 40\% covariability between rainfall and Southern Oscillation (Zheng and Frederiksen, 2006) and the National Institute of Water and Atmospheric Research (NIWA) considers the association robust enough to recommend management actions and planning on the basis of the SOI (Porteous et al 1998).

\section{STUDY AREA}

The South Island of New Zealand is split from north-east to south-west by the Southern Alps, a major mountain range rising from sea level to $2500 \mathrm{~m}$ within 20-40 kilometers of the west coast. Canterbury straddles the middle of the South Island on the eastern side of this mountain barrier and two broad regions can be defined. Western Canterbury is mountainous, extending from the divide of the Southern Alps out to the eastern foothills. Eight major rivers have their upper catchments in this region, collecting the heavy rain in the Alps and draining out through the foothills to the eastern plains and the sea. To the east of the foothills are the extensive Canterbury Plains, stretching from the base of the Hunter Hills in the south to the Conway river in the north. The Canterbury region has been divided into two 'mega-catchments in an attempt to isolate the effect of the ENSO events on the predominant west-east precipitation trend (Figure 1). The 'Alpine' catchment extends from the divide of the Southern Alps east to the crest of the foothills and from the southern edge of the Rangitata River catchment in the south to the northern edge of the Waiau River catchment in the north. Hence the upper catchments of the Rangitata, Ashburton (North and South Branches), Rakaia, Waimakariri, Hurunui and Waiau Rivers have been included. The eastern limit of the Alpine catchment has been set at the flow gauge at or near the gorge through the eastern foothills, for each of these rivers. Hence any drainage which joins these rivers upstream of the 'gorge' flow gauge is included in the Alpine catchment. The Waitaki and Clarence Rivers were not included in the study area.

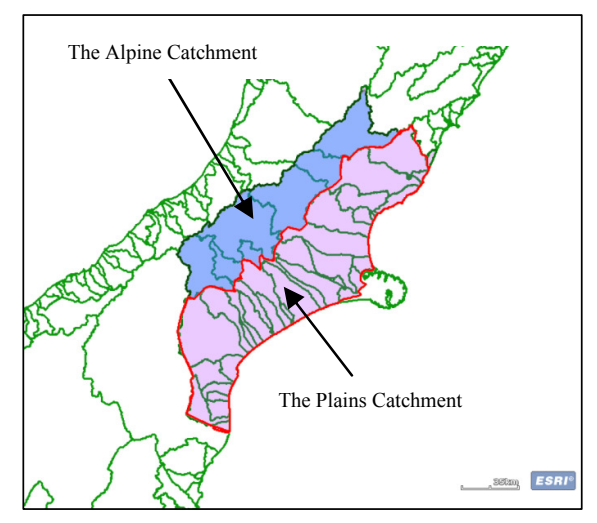

Figure 1 Canterbury Catchments 
The 'Plains' catchment extends from the crest of the foothills out to the coast and from just north of the Waitaki River mouth in the south, to the Conway River catchment in the north. In the foothills, the catchment of any drainage which flows east is included in the Plains catchment including any drainage which runs into one of the main Alpine rivers below their 'gorge' flow gauges. The area of the Alpine and the Plains catchments are 9952 and $19423 \mathrm{~km}^{2}$, respectively, making a total area of $29375 \mathrm{~km}^{2}$ for the study area of Canterbury region.

\section{WATER BUDGET}

The water budget for a catchment area can be expressed as follows:

$\Delta \mathrm{S}=$ Input - Output

Where the input is mainly from precipitation and river inflows to the catchment, while the output is mainly evapotranspiration and any river outflows. As average annual flows are considered in this hydrological budget, and assuming that surface and subsurface storage would not change significantly over years, $\Delta \mathrm{S}$ can be a good estimate for the recharge or discharge of the ground water system in the study area. It is expected however that over the long term there should be an excess of inputs over outputs ie $\Delta \mathrm{S}>0$ reflecting unconstrained abstractions from the groundwater system such as groundwater losses to the ocean. Water budgets for the Alpine and Plains catchments are calculated for the two strongest La Nina events and the two strongest El Nino events since 1980. The SOI have been obtained in standardised Tahiti- Standardised Darwin format from the National Center for Atmospheric Research's, Climate and Global Dynamics unit. Standardising has been done using the Trenberth approach in order to maximise the signal.

\subsection{Rainfall}

Monthly average rainfall data for the period 1970 to 2010 was downloaded from CliFlo: NIWA's National Climate Database on the Web (www.cliflo.niwa.co.nz), and then loaded as the data source for the ArcGIS program (ESRI Inc). The data was consolidated into three broad data sets for each of the climate conditions to be evaluated: 41 year annual rainfall (All, Long term Average=LTA, for the year July to June), and annual rainfall for the selected El Nino and La Nina years. Each of these broad data sets were further dissected into an Alpine and Plains data set for each of the climate scenarios to be evaluated making 9 data sets.

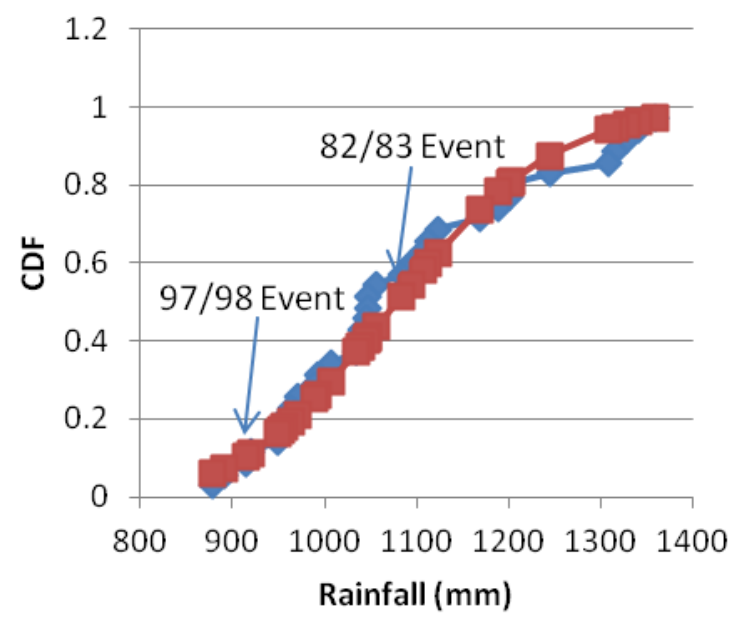

$\longrightarrow$ Observed $\rightarrow$ Gamma

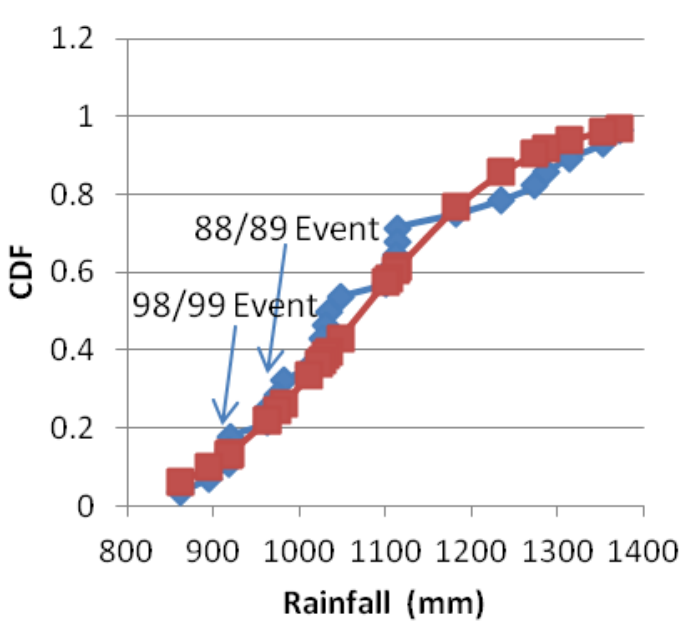

$\leadsto$ Observed $\rightarrow$ Gamma

(a) El Nino Period

(b) Al Nina Period

Figure (2) Fitted Gamma Distribution Showing Selected El Nino and Al Nina Events

The Gamma distribution (Ben-Gai et al. 1998) has been fitted to the El-Nino and the La Nina periods, and was not rejected under diagnostic tests based on comparison of the historical and modeled cumulative distributions (CDFs) and histograms, in addition to Kolmogorov Smirnov goodness of fit test, $\mathrm{Chi}^{2}$ goodness of fit test and the Filliben correlation coefficient. Figure 2 shows the modeled cumulative distributions for the El Nino and the La Nina periods compared to their corresponding observed values, indicating where the selected two years for each of these climate patterns occur. Figure 2 shows that the two selected events for the Al Nina period lie in the lower tail of the distribution, as expected. However, the figure shows that the 
82/83 El Nino event, which has the highest El Nino negative signal, lies in the upper half of the El Nino distribution. This indicates the uncertainty associated with the impact of the SOI on the rainfall pattern over Canterbury. Weaker signals, either for El Nino or La Nina, would have higher variability. This would make it more difficult to assess if included in the study. It is noted that a longer period $(1950-2009)$ has been used to fit the Gamma distribution, as there is no need to include the river flow data, which of course is needed for the water budget. Thus, higher El Nino and Al Nina signals than the selected ones are included in the fitted distribution. Rainfall isohyets were also formed using the above process, from raw data obtained from a NIWA 1970 -2003 modeled annual rainfall dataset plotted on a $0.005^{\circ}$ lattitude longitude grid.

\subsection{River Flows}

Major Alpine rivers that also transect the Plains include the Rangitata, Ashburton, Rakaia, Waimakariri, Hurunui, and Waiau rivers. On the Plains catchment, smaller rivers were included in the water balance calculation. These include Otaio, Pareora, Hinds, Opihi, Orari, Selwyn, Ashley, Kowai, Waipara and Conway rivers. The monthly average data were used to calculate the average annual volume of each river for the same years (July 1982-June 2009). Since the study area was divided into two regions (Alpine and Plain Catchments), total annual volume of all the rivers in each catchment were calculated separately.

\subsection{Evapotranspiration}

Evapotranspiration (ET) is a key component of the water balance but is poorly constrained in the Canterbury region. Much effort has been put into modeling surface recharge of various Canterbury aquifer systems (Thorpe \& Scott, 1999; White et al, 2003; Scott 2003), as well as evaluating potential evapotranspiration (PET) at catchment scales (Weingartner and Pearson, 2001; Tait and Woods 2006). However there appears to be no physical measurement of actual evapotranspiration (AET) in Canterbury, even at site specific scales (J. Hunt, Landcare research, personal communication, 2010). It is this AET that is required for water balance calculations.

PET is a measure of the environmental demand for ET and may be calculated from the climatic variations of sunshine hours, relative humidity, air temperature and wind run. AET is then dependent on the availability of water to satisfy the PET demand and the degree to which soil and vegetation regulate the evaporation. The ratio of AET/PET is therefore a complex one which is highly variable, depending on water availability (precipitation and/or irrigation) and land use. Hence even direct measurement of AET over a small scale is unlikely to reflect the actual situation over a larger spatial or temporal scale. In the complete absence of directly measured data, we are left to make best estimates of AET based on PET derived from actual and modeled data, and the modeled relationships between AET and PET. The dramatically different soils, land use and climate over the Plains catchment as compared to the Alpine Catchment meant that different methods for estimating AET were considered appropriate for the two catchments. Changing land uses over the study period further complicates the picture.

\section{Evapotranspiration Estimate for the Plains Region}

The only study available in the literature, which attempts to calculate changing AET with increasing irrigation at a catchment scale is that by Schmidt et al (2009) in which ET is modeled for the Orari catchment in South Canterbury. An agro-hydrological, soil-moisture driven demand model was used to estimate ET resulting from changes in the extent of irrigated land use. The Orari catchment seems likely to provide a good model for the rest of Canterbury plains catchment as it simulates a braided river system stretching west-east from the mountains of the Canterbury foothills to the coast. The Orari modeling figures were used to derive AET/PET ratios for the Canterbury Plains.

\section{Evapotranspiration Estimate for the Alpine Region}

There is a complete lack of measured AET data for the Canterbury high country. In the past, some studies have applied a blanket annual rate of $700 \mathrm{~mm}$ to catchments which receive greater than $800 \mathrm{~mm}$ of precipitation based on rainfall/runoff studies in some catchments (McKerchar and Pearson,1997). Annual and spatial variability has been considered to be very low across much of the South Island (Finkelstein, 1973; Mckerchar et al, 1998). A comparative study of hydrology in the Swiss Alps and Southern Alps of New Zealand generated an ET lapse rate of $-17 \mathrm{~mm} / 100 \mathrm{~m}$ (Weingartner and Pearson, 2001), close to the 20mm/100m stated by Toebes in his 1972 water balance calculations for New Zealand.

For the purposes of this study, Penman PET data was obtained for Hanmer Springs. The 1982-1992 data is generated from the NIWA Virtual Climate Station Network while data post 1997 is calculated from actual climate data. The PET was then altitude corrected using Weingartner and Pearson (2001) rate of - 
$17 \mathrm{~mm} / 100 \mathrm{~m}$ to an approximate catchment average altitude of $1000 \mathrm{~m}$. Hanmer Springs lies at $600 \mathrm{~m}$ resulting in an altitude correction of $-68 \mathrm{~mm}$.

\section{RESULTS AND DISCUSSIONS}

The water budget calculated in this study did not balance, particularly for the Alpine Catchment. The excess/deficit figures for the Plains catchment appeared reasonable and may reflect real climate variations. The large deficits in the Alpine catchment appear unlikely, especially given the lack of a significant groundwater reservoir in the catchment. The Alpine deficits are likely to have resulted from underestimation of rainfall, most likely related to the physical location and the lack of a good network of rain gauge sites. The whole Canterbury region figures were impacted by the deficits in the Alpine catchment.

\subsection{Water Balance for the Alpine Catchment}

In an attempt to improve the water budget results for the Alpine region, the following key assumptions have been made:

- $\quad$ River flow data, being a measured flow at the exit points of the Alpine catchment, is a reasonably accurate figure. Evapotranspiration is likely to be moderately well due to the lack of complicating land use effects and the excess of rain over PET. Rainfall has the greatest degree of uncertainty.

- $\quad$ Net storage in the Alpine region is negligible over a July/June year.

- Ground water recharge in the alpine region is negligible, as ground water aquifers are confined to the river beds. There may be loss of some water to fault zones.

Using these assumptions the rainfall for the Alpine catchment can be directly estimated from an addition of river flows and ET, hence reducing the underestimation errors. These values (Table 1) appear reasonable for New Zealand alpine catchments with Weingartner \& Pearson (2001) deriving an average precipitation of $2672 \mathrm{~mm}$ for catchments east of the main divide. NIWA's modeled figures for the Waimakariri, Rakaia and Rangitata catchments are between $2204 \mathrm{~mm}$ and $2624 \mathrm{~mm}$. Hence it appears likely that the rainfall calculated in this study from isohyets derived from measured rainfall data, is underestimating rainfall in the Alpine catchment by around $25-28 \%$. Water balance figures for all catchments have been recalculated using the new estimates for Alpine rain, and were presented in Table 1.

Estimates in the range of $69 \mathrm{~m}^{3} / \mathrm{sec}\left(1500 \mathrm{~m}\right.$ altitude) to $170 \mathrm{~m}^{3} / \mathrm{sec}(500 \mathrm{~m}$ altitude) have been used in previous studies.(Weingartner \& Pearson 2001). The Weingartner \& Pearson lapse rate of $-17 \mathrm{~mm} / 100 \mathrm{~m}$ has been factored into the AET calculation of this study. Weingartner \& Pearson considered that the use of the combined Swiss Alps and Southern Alps values presented in his paper should replace the common practice of using an arbitrary evaporation rate of $700 \mathrm{~mm} /$ year $\left(220 \mathrm{~m}^{3} / \mathrm{sec}\right)$ as proposed by McKerchar in 1998. Rainfall appears to be higher and ET lower in La Nina years compared to El Nino years in the Alpine catchment. This results in higher river flows in La Nina years. However both ENSO data sets produced lower rain than the long term average.

\subsection{Water Balance for the Plains Catchment}

The long term budget for the Plains catchment gives an excess of $94 \mathrm{~mm}$. This appears to be a reasonable figure of about $11 \%$ of rainfall and represents the water available for recharge of groundwater. It should be noted however that this is significantly less than the $30 \%$ of rainfall assumed as variable source recharge in the Environment Canterbury first order groundwater allocation methodology (Aitchison-Earl \& Sanders 2004). El Nino year budgets result in a deficit of $-66 \mathrm{~mm}$ reflecting the lower rainfall and higher ET experienced in these years. This deficit is likely to result in a drawdown of the groundwater resource as this is the reservoir which will provide the water for continuing river flows despite reduced rainfall. The La Nina budget deficit of $-10 \mathrm{~mm}$ is more surprising given that previous studies indicated increased eastern rainfall (Gordon 1986, Mullan 1996 and 1998, Kidson and Renwick, 2002) and reduced ET. In fact this study has resulted in lower rainfall during the La Nina years than the long term average. With lower rainfall one might reasonably expect higher ET, however ET has been calculated at lower than long term average. This may be the result of increased cloud and cool easterly wind and temperatures, without a corresponding increase in rain.

\subsection{Water Balance for whole Canterbury Region.}

This study indicates an excess of water available for ground water recharge over the long term, while El Nino years are likely to produce a deficit and La Nina years are much less certain in their effect. The selected El Nino and La Nina events, despite having the strongest signals for the period included in the water budget 
study, were not in the lowest tail of their distributions. To the contrary, the 82/83 El Nino event with a strong SOI index of -45.9, was almost in the middle of the rainfall distribution for El Nino period. This indicates the variability associated with the impact of the SOI on Canterbury rainfall. As the Alpine catchment provides Canterbury rivers, which run through its plains, with their most share of water, it is important to study the impact of the SOI on each region separately, and also on the whole Canterbury region for proper management of its water resource.

Table 1 Regional water balance components based on recalculated Alpine rainfall

\begin{tabular}{|c|c|c|c|c|c|c|c|c|}
\hline Region & $\begin{array}{c}\text { Rain } \\
\text { mm }\end{array}$ & $\begin{array}{c}\text { Rain } \\
\text { m }^{3} / \text { sec }\end{array}$ & $\begin{array}{c}\text { River } \\
\text { flow } \mathrm{mm}\end{array}$ & $\begin{array}{c}\text { River flow } \\
\mathrm{m}^{3} / \mathrm{sec} \\
\end{array}$ & $\begin{array}{c}\mathbf{E T} \\
\mathbf{m m}\end{array}$ & $\begin{array}{c}\text { ET } \\
\mathrm{m}^{3} / \mathrm{sec}\end{array}$ & $\begin{array}{c}\text { Balance } \\
\text { mm }\end{array}$ & $\begin{array}{c}\text { Balance } \\
\mathrm{m}^{3} / \mathrm{sec}\end{array}$ \\
\hline \multicolumn{9}{|c|}{ Alpine Catchment } \\
\hline El Nino & 2446 & 772 & 1741 & 550 & 705 & 222 & 0 & 0 \\
\hline La Nina & 2575 & 813 & 1948 & 615 & 627 & 198 & 0 & 0 \\
\hline All Years & 2341 & 739 & 1674 & 528 & 666 & 210 & 0 & 0 \\
\hline \multicolumn{9}{|c|}{ Plains Catchment } \\
\hline El Nino & 665 & 409 & 1114 & 686 & 509 & 313 & -66 & -40 \\
\hline La Nina & 715 & 440 & 1244 & 766 & 479 & 295 & -10 & -6 \\
\hline All Years & 827 & 509 & 1097 & 676 & 494 & 304 & 94 & 58 \\
\hline \multicolumn{9}{|c|}{ Canterbury Region (Alpine + Plains) } \\
\hline El Nino & 1268 & 1181 & 736 & 686 & 576 & 536 & -44 & -40 \\
\hline La Nina & 1345 & 1253 & 823 & 766 & 530 & 493 & -7 & -6 \\
\hline All years & 1340 & 1248 & 725 & 676 & 552 & 514 & 62 & 58 \\
\hline
\end{tabular}

\section{CONCLUSIONS AND RECOMMENDATIONS}

This study has produced water balances for the western (Alpine region) and eastern (Plains region) areas of Canterbury for both the long term data sets and selected El Nino and La Nina years, with the highest SOI signal. Accessibility of measured data has been a major challenge and generally the data quality is not good due to the high variability and the low intensity of the monitoring network, especially in the Alpine region. Hence the water balance results should be treated with caution and are likely to represent a broad picture rather than reliable figures. Using currently available data, rainfall in the Alpine catchment was underestimated by around $28 \%$ while evapotranspiration in the Plains area is very poorly constrained.

Strong ENSO events appear to have an effect on the water balance components. La Nina appears to produce increased rainfall, and decreased evapotranspiration relative to El Nino years across the entire region. Long term figures produce a water balance excess for the Plains of around $11 \%$ of rainfall. This is available for recharge of the ground water resource. In El Nino years, however, there is likely to be a water balance deficit which in this study was calculated at around $10 \%$ of rainfall. While the La Nina years also show a water balance deficit of around $1 \%$ of rainfall, the degree of uncertainty around data makes the likelihood of excess or deficit inconclusive.

It is recommended that a significant investment is required to improve the quality of data available for the evaluation of Canterbury's critical water resources. The areas which will significantly improve the estimations of water and water availability in the Canterbury region are;

- $\quad$ an increased rain gauge distribution especially in the alpine regions,

- a widespread system for direct measurement of actual evapotranspiration rates,

- an investigation of solutions for the measurement of outflows of major braided river systems.

\section{References}

Aitchison-Earl P, S. D., Sanders R (2004). Ground Water Allocation Limits: Guidelines for the Canterbury Region. E. Canterbury. Christchurch, Technical Report. Environment Canterbury.

Basher, R. (1998). The 1997/98 El Nino Event: Impacts, Responses and Outlook for New Zealand. New Zealand Ministry of Research Science and Technology, Report 73. Wellington.

Ben-Gai, T., Bitan, A., Manes, A., Alpert, P., Rubin, S. 1998. Spatial and Temporal Changes in Rainfall Frequency Distribution and Pattern in Israel.Theoretical Applied Climatology 61. 
Mohssen et al., Impact of El Nino and La Nina Weather Patterns on Canterbury Water Resources

Baalousha, H. 2008. Water Balance Model for the Ruataniwha Basin. Environmental Management Group Technical Report EMT 08/05. Hawkes Bay Regional Council, Napier.

Finkelstein, J. 1973. Survey of New Zealand Tank Evaporation. Journal of Hydrology (NZ) 12 (1).

Freestone, H.J. 1981. A Short Analysis of Regional Catchment Rainfall and Runoff Data from Volume 1 of the Catchment ReGISter Publication 1981. Water and Soil Science Center, Christchurch, Report No WS 499. Ministry of Works and Development.

Gordon, N.D. 1986. The Southern Oscillation and New Zealand Weather. Monthly Weather Review 114.

Kidson, J.W., Renwick, J.A. 2002. Patterns of Convection in the Tropical Pacific and Their Influence on NZ Weather. Int. J. of Climatol. 22.

McKerchar, A.I., Pearson, C.P. 1994. Forecasts of Seasonal River Flows Using Southern Oscillation Index. Journal of Hydrology (NZ) 32 (2)

McKerchar, A.I., Pearson, C.P., Moss, M.E. 1996. Prediction of Summer Inflows to Lakes in the Southern Alps, Using Spring Oscillation Index. J. of Hydrology 184.

McKerchar, A.I., Pearson, C.P. 1997. Quality of Long Flow Records for New Zealand Rivers. Journal of Hydrology (NZ) 36 (1).

McKerchar, A.I. Pearson, C.P., Fitzharris, B.B. 1998. Dependency of Summer Lake Inflows and Precipitation on Spring SOI. Journal of Hydrology 205.

Morgan, M, Bidwell, V. Bright, J. McIndoe, I. Robb, C. 2002. Canterbury Strategic Water Study. Report Number 4557/1 prepared for Ministry of Agriculture and Forestry, Environment Canterbury, Ministry for the Environment by Lincoln Environmental.

Mullan, B. 1996. Effects of ENSO on NZ and the South Pacific. (in Prospects and Needs for Climate Forecasting-Royal Soc of NZ Misc series 34)

Mullan, A.B. 1998. Southern Hemisphere Sea-surface Temperatures and their Contemporary and Lag Association with NZ Temperature and Precipitation. Int. J. of Climatol. 18

Porteous, A.S., Mullan, A.B., Basher, R.E. 1998. New Zealand Climate and La Nina: Prospects for 1998/99. NIWA Report WLG/42.

Schmidt, J. Kienzle, S.W. Srinivasan, M.S. 2009. Estimating Increased Evapotranspiration Losses caused by Irrigated Agriculture as Part of the Water Balance of the Orari Catchment, Canterbury, New Zealand. Journal of Hydrology (NZ) 48 (2).

Scott, D. 2003. Net Use of Groundwater for Irrigation- A Review of the Concept. Investigations and Monitoring Group, Technical Report U04/53. Environment Canterbury, Christchurch.

Scott, D. (2004). Groundwater Allocation Limit: Land based recharge estimates. Technical Reports. E. Canterbury, Environment Canterbury: 39.

Tait, A., Woods, R. 2006. Spatial Interpolation of Daily Potential Evaotranspiration for New Zealand Using a Spline Model. Journal of Hydrometeorology 8.

Thorpe, H.R., Scott, D.M. 1999. An Evaluation of Four Soil Moisture Models for Estimating Natural Ground Water Recharge. Journal of Hydrology (NZ) 38 (2).

Toebes, C. (1972). The Water Balance of New Zealand. Journal of Hydrology (NZ) 11 (2).

Weingartner, R. and Pearson, C. (2001). A Comparison of the Hydrology of the Swiss Alps and the Southern Alps of New Zealand. Mountain Research and Devlopment 21 (4)

White, P.A., Hong, Y-S. Murray, D.L. Scott, D.M. Thorpe, H.R. (2003). Evaluation of Regional Models of Rainfall Recharge to Groundwater by Comparison with Lysimeter Measurements, Canterbury, New Zealand. Journal Of Hydrology (NZ) 42 (1).

Woods, R., Hendrikx, J., Henderson, R., Tait, A., 2006. Estimating Mean Flow of New Zealand Rivers. Journal of Hydrology (NZ) 45 (2).

Zheng, X. and Frederiksen, C.S (2006). A Study of Predictable Patterns for Seasonal Forecasting of New Zealand Rainfall. Journal of Climate, 19 (13). 